\title{
Prevalent Leadership Styles and their Compatibility to the New Ways of Working in General Hospitals in Nigeria
}

\author{
Article by Maclawrence Kolapo Famuyiwa \\ Chest Clinic, Apapa General Hospital, Apapa, Lagos, Nigeria \\ E-mail: maclawrencefamuyiwa@yahoo.com
}

\begin{abstract}
Context: Hospital patients desire more flexibility in health care delivery, hence developing new ways of working (NWW), and making the leadership styles in these hospitals to be compatible will ensure this.

Design: Prevailing leadership style and its compatibility to New Ways of Working were assessed by self-administered and pretested questionnaire. Descriptive statistics to elucidate on the demography of the respondents were done, mean score and standard deviation values were used to examine the variables. Spearman's rho correlation was used to identify the association in the responses.

Setting/Participants: A stratified sampling method was used to select samples for this study, and these samples were surveyed for their views on the prevalent leadership styles and how this prevailing leadership style can accommodate NWW.

Outcome measures: Some features of both task-oriented and person-centered leadership styles were identified. Then the respondents' agreement to the existence of these features of each leadership style and how NWW could be accommodated was examined.

Results: 100 questionnaires were distributed, 81 (81\%) of the questionnaires were returned. The mean score of the two leadership styles were $2.11 \pm 1.11$ and $2.16 \pm 1.11$ respectively with $a$ significant correlation ( $r=0.871, p<0.001$ ). The compatibility of prevalent leadership style to 'New Ways of Working' was $4.29 \pm 1.74$.

Conclusion: Both task-oriented and person-centered leadership are present, and little adjustment are necessary for NWW to be accommodated. NWW will allow patients to overcome the encumbrances of busy schedules robbing them off an access to quality health care.
\end{abstract}

Keywords: Compatibility, Leadership styles, New Ways of Working, General Hospitals.

\section{Introduction}

Over the years, a change in patients' behavior has been noticed in the way they wish to be attended to in hospitals, especially the public hospitals in Nigeria, where hitherto, they had suffered a great inconsideration in the way they receive care from various hospital staff and are given clinical appointments not taken cognizance of the peculiarity of the type of work they do or the traffic quagmire the metropolitan lifestyles imposes on their easy movement. The new trend being proposed now, through NWW, is for them to be able to determine how and when they wish to be attended to by these hospital staff, so it behooves on these staff to be able to adequately respond to this by developing a new way of working (NWW).

The main clog in this is that these patients ability to determine when and how they would receive care from the health providers in these General Hospitals, apart from the hospital staff themselves, is the leadership and the styles of leadership in these hospitals, it is thus the mandate of this study to establish the prevalent leadership style in these hospitals and how this type of leadership can be able to accommodate NWW, or if possible find out an alternative style of leadership that will be most apropos for NWW. 
Also it is a known fact that medical practitioners in General Hospitals have devised a particular way in which they are expected to carry out their functions in the hospitals, they have clinic days in which they meet their patients, and patients' absenteeism is greatly abhorred and resented. Consulting rooms are traditionally the meeting place, and rarely do they extend consultation to outside these rooms to accommodate patients that fail to meet up appointments. Even the governments, who are their employers, also frown at the idea of health providers, under their employment, to offer professional services outside the confines of consulting rooms in the General Hospitals, this is not hiding the fact that many of these health care providers when given this flexibility have not turned around in the past to end up converting General Hospital patients to theirs in order to augment their income with money realized from privately treating these patients.

There is therefore a serious need for further research and capacity enhancement in these General Hospitals in order for a new way of working to be developed so as to meet the increasing health needs and more say of the patients in how they receive health care, which has to be at their own convenience and at the most appropriate place and time, which will be made feasible with the use of latest technological developments. This also has to put into consideration the flexibility in the way the health workers are expected to carry out their work, and also for the leadership styles in these hospitals to be receptive to all these changes that the implementation of NWW may exhume, yet still able to offer a good management guide to ensure that not only are patients satisfied but also the staff, as well as the realization of providing the best health care to these patients.

'The New Ways of Working' (NWW) being proposed to make the patients to be incharge of how they receive hospital services, has various definitions (Baane, Houtkamp \& Knotter, 2010; Volberda, Jansen, Tempelaar \& Heij, 2010)' For example, Bijl (2009) defined it as a vision whereby recent developments in information technology act as a catalyst for a better design and management of knowledge work. This involves the reconstruction of the physical work place, the organizational structure and culture, the management style as well as a better design and management of knowledge worker and his manager. This definition has been established to encompass all other definitions as it includes the four most important focus areas (people, organization, work environment and technology).

NWW is thus important to ensure that patients especially those attending out-patient clinics and seeking specialist consultations in General Hospitals can be in the confines of their offices and homes as well as other places and still be able to receive quality healthcare from their doctors and other hospital staff making use of latest technologies most notably social media such as Facebook, Twitter, Skype, Whatsapp, Oovoo, Join me etc, and this will also ensure that these health workers will also be able to flexibly attend to the health needs of their patients from anywhere without compulsorily needing to be physically present within the hospital premises except when they need to attend to emergency cases. NWW involves an employee successfully juxtaposing his work with the working environment, and the flexibility of the work ambience to suit various sorts of activities (Bijl, 2007;,Bijl, 2009; Egmond van (2010), which often resulting in offices of these employees being mere meeting points for staff and should be designed in such a way that staff gladly physically meet each other there to work together (Bijl, 2009).

The emphasis NWW places on the result demands a different organization of the work place, the organizational structure and the style of leadership. Additionally, the current technology offers the opportunity to work without the restriction of time or location (Bijl, 2009). The New Ways of Working explores the separation of the constraints of time and place from staff flexibility and the usage of innovative technological developments, resulting in the rendering of a satisfying service to the patient. It is also believed that NWW will offer staff the opportunity to combine work and home life better, enabling them to work with more flexibility, as well as further their personal development (Houtkamp \& Knotter, 2010). To effectively achieve NWW it then means that staff will now also be expecting different opportunities than they have ever had, which means a change in the leadership style is inevitable in order for NWW to be accommodated. 
Leadership on the other hand, has been defined as a process of influencing others for the purpose of performing a shared task (Fiedler, 1967). Different authors have identified different types of leadership styles, Lewin, Lippit and White identified three major types of leadership styles they termed authoritarian, democratic and laissez-faire, and since then other leadership styles have been defined (Lewin, Lippit \& White, 1939).

Fiedler (1964) recognized two styles of leadership, he called task-oriented, and relation-oriented or person-centered. Fiedler (1966) described the task-oriented leader as the one that pays more attention on the job, and takes a special interest on the specific tasks assigned to each employee to reach goal accomplishment. This leadership style pays very little attention to the team needs, and so may not be motivational style of leadership to adopt, and so it requires a very close supervision and control before the expected results could be achieved, this style of leadership was called the deal maker (Rowley \& Roevens, 2000).A task-oriented leader dictates to the followers what has to be done, the best way to do it and with the leader partaking in the performance of the work (Klutymans, 2010; Taberno, Chambel, Curral \&Arana, 2009).It is thus concerned with the degree to which the leader takes the initiative for activities within the group.

Person-centered leadership, on the other hand, refers to the level to which the manager pay attention to the well-being of his staff. This type of leaders exhibits great appreciation for properly carried out tasks, and treats the followers as equals by emphasizing the difference in work satisfaction and enhancing the sense of self-worth amongst staff. A people-oriented leader supports, trains and develops his personnel, so as to ensure effectiveness and efficiency, and he does so by increasing job satisfaction and genuine interest to do a good job (Firdler, 1966).

A person-centered leadership, staff support, the realization of connections with staff and collaboration have been suggested to be the essential ingredients of NWW (Bijl, 2007; Bijl, 2009),but some other authors have rather suggested results-oriented leadership which corresponds to taskoriented leadership instead of a person-centered leadership to be that to be included as part of the essential ingredients of NWW De Leede \& Kraijenrink, 2014). This will be explored in further details in this study, with the aim of establishing the prevailing leadership style between task-oriented and relation-oriented leadership styles presently being used within the General Hospital set ups in Nigeria. 'New Ways of Working' should, however, offer staff the freedom to show and establish important competences such as responsibility, flexibility and entrepreneurship (Bijl, 2009).

This study will also explore how these style of leadership as described by Fiedler ${ }^{6}$ will affect the introduction of new ways of working which this study tends to investigates among hospital staffs in a General Hospital in Nigeria. The study becomes necessary to ensure that the desire of patients presently attending out-patients clinics in General Hospitals in Nigeria to have flexibility in the way they receive care from hospital staff, not only within the confines of the hospitals but also outside of them, finally becomes a fruition.

\section{Methodology}

\section{Description of study area}

The study was conducted in a General Hospital situated in Apapa, Lagos, Nigeria. The location of the hospital is the home of two most important ship ports in Nigeria which handle approximately $60 \%$ of ship cargo traffic in Nigeria, it is home to many Nigerians and quite a number of Lebanese, Indians, and Chinese nationals. The hospital, where the study was conducted, serves the residents of Apapa, and also those of Ijora, Orile, Ajegunle, Amukoko etc that are immediate its suburbs. The hospital is multi-specialty, with departments of Obstetrics and Gynaecology, Paediatrics, Medicine, Surgery, Community Medicine, Dentistry and also facilities for nursing, physiotherapy, pharmacy, laboratory, medical social work.

The respondents used for this study consists of management and non-management staff of this Hospital, where NWW is not being presently practiced. A preliminary study done showed that about 357 staff are listed in the nominal roll of the hospital, 25 of them belong to the management staff who 
constituted the Hospital Management Committee, the Head of Departments and Head of Sub units, while the rest can be categorized as the non-management staff.

\section{Sampling technique/ sampling size}

The sample size used in this study was calculated using Taro Yamane formula as follows:

$$
\begin{aligned}
& \mathrm{n}=\frac{N}{1+\mathrm{N}}(\mathrm{e})^{2} \\
& \text { Where: } \\
& \mathrm{n}=\text { Sample Size } \\
& \mathrm{N}=\text { Elements of population in this study is } 357 \\
& \mathrm{e}=\text { Error of sampling, in this study is } 10 \text { percent or } 0.10 \text { proportion. }
\end{aligned}
$$

Therefore, substitution in the formula:

$$
\begin{aligned}
\mathrm{n} & =\underline{357} \\
& 1+357(0.10)^{2} \\
& =\mathbf{7 8 . 1 2}
\end{aligned}
$$

Furthermore, owing to the diverse professional status of the respondents involved in this study, a stratified sampling method was adopted for this study by drawing separate random samples from amongst the different professional cadres found in this General Hospital: Doctors, Dentists, Pharmacists, Physiotherapists, Administrators, Accountants, Medical Records Officers, Nurses and Other Staff. This method was also adopted to draw random samples between the management and non-management staff.

\section{Data collection method}

This study used questionnaire for data collection since this is particularly appropriate for deductive research providing an easily accessible and controllable way for collecting and explaining data. I sought for expressions of interest from all surveyed respondents using an introductory letter explaining the aim of the study and the anonymity of the answers, polite reminders were personally given by me three days to and repeated again a day to the deadline for the collection of the questionnaire. It has been stated that re-notification and follow-ups increase the response rate (Cooper, 2003).The list of concepts also accompanied the questions for clarification purpose.

I designed the study instrument after a rigorous literature review (Memish, et al, 2014; WHO, 2013; Gautret, Benkouiten, Salaheddine, Belhouchat, Drali \& Parola, 2013; Al-Tawfik \& Memish, 2014). After an initial draft of the questionnaire was designed, it was validated in 2 steps. Firstly, the study instrument was discussed with the senior academics versed in research work to give their expert opinion with respect to its simplicity, relativity and importance. Secondly, a pilot study was conducted by the selection of a small sample of health care professionals $(n=9)$ who gave their opinions on making the questionnaire simpler and shorter. Participants from all professions working within the hospital studied were selected for the pilot study. Amendments from the participants were considered and used in modifying the questionnaire, while ensuring its consistency with the published literaturere view (Memish, et al, 2014; WHO, 2013; Gautret, Benkouiten, Salaheddine, Belhouchat, Drali \& Parola, 2013; Al-Tawfik \& Memish, 2014). After a thorough discussion, I finalized the questionnaire and subsequently distributed to the participants for their response. The data of the pilot study was not used for the final analysis.

The first section of the questionnaire consists of the questions on demographic information: Gender, Age, Education level, Specialty/Department, and job functions. The rest of the sections contains questions on the prevailing leadership style and the compatibility of present leadership style to the introduction of 'New Ways of Working'. Responses were evaluated through 7 point Likert scale of agreement, A score of 1 was given to strongly agree, 2 to agree, 3 to somewhat agree, 4 to 
neither agree nor disagree, 5 to somewhat disagree, 6 to disagree and 7 to strongly disagree. A mean score of < 5 was considered as agreement while score of $\geq 5$ was taken as disagreement.

Furthermore, a snapshot approach or cross-sectional study design was employed as the study was conducted at a specific moment in time. As such, there was no time available to conduct a longitudinal study. It was also desirable to know the state of affairs at this specific moment in order to be able to take action in the short term. The primary source of data collection for this study was through the use of validated questionnaire and data was collected in May, 2016.

\section{Reliability and validity of data collection instrument}

\section{Reliability}

Reliability "refers to the degree to which observes scores are free from errors of measurement" (Dooley, 2009). Reliability is measured by the consistency of the scores". Cronbach's alpha (Cronbach, 1951), was used to determine the homogeneity of the data collected. The internal reliability of the leadership style questionnaire was determined.

The contents of the questionnaire that was finally used, have reliability coefficient calculated using SPSS v.20 and the value of Cronbach's alpha (Cronbach, 1951) was 0.81, Cronbach's Alpha values higher than 0.7 is considered reliable (Nunnally, 1978).

\section{Validity}

Validated questionnaire was used in this study in order to increase reliability. A validated questionnaire incorporates validity which reflect whether the research is actually measuring what it is supposed to measure, this is the extent to which the collection of data, the techniques used and the analysis ensured inter-dependent findings (Saunders, Lewis. Thornhill, Booijl \& Verckens, 2011).

\section{Data analysis method}

The data generated from this study was analysed using SPSS version 20. Mean and standard deviation were employed for the univariate analysis. Bivariate relationships between 7-item Likert scales were analysed using Spearman's correlation coefficient $r$ for correlation, because the measurement scale is ranked (Bryman \& Bell, 2011).

\section{Results}

\section{See Table 1}

Table 1 shows that $69.1 \%$ of the respondents were female while $30.9 \%$ were male. This indicates that both male and female sexes are represented.

\section{See Table 2}

Table 2 reveals that $80.4 \%$ of the respondents were between 26 and 50 years age range, out of which $60.3 \%$ are within the age group 41 and 50 years. Those below 25 years and those above 56 years of age were $1.2 \%$ respectively of the respondents. Overall, the data shows that all working age groups are represented.

\section{See Table 3}

Table 3 indicates that $65.5 \%$ of the respondents have more than a bachelor degree, with $20.8 \%$ of these group of respondents even having a post-graduate degree, $9.9 \%$ had OND/NCE, $21.0 \%$ had a School of Nursing certificate, and only $2.5 \%$ had a Secondary School certificate, this is a confirmation that the respondents are well educated to understand the questions and provide reliable answers.

\section{See Table 4}

Table 4 shows that the core staff of the hospital, supposedly including the Nurses, Doctors, Dentists, Pharmacists, Physiotherapists and Laboratory workers constituted $76.6 \%$ of the respondents, 
Texila International Journal of Public Health

Volume 4, Issue 4, Dec 2016

an indication that all the core hospital staff needed for the purpose of this research are well represented.

\section{See Table 5}

The non-managerial staff among the respondents as revealed in Table 5 constituted $74.1 \%$ of the respondents while $25.9 \%$ were managerial staff which include Head of Departments, Head of subunits and members of Hospital Management Committee, a confirmation of a good representation of all cadres of staff in the sample.

\section{See Table 6}

Table 6 shows the respondents agreed most with the statement that their leaders have a strong orientation towards employees under them getting the job done and at the scheduled time. This statement on the average has a mean of 1.64 and the standard deviation of 0.97 which is an indication that the study instrument is a good measure of this variable. The average mean of the table is 2.11 which indicates an agreement by the respondents that task-oriented leadership is prevalent and the average standard deviation of 1.11 indicates that the instrument is a good measure of the variable.

\section{See Table 7}

Table 7 shows that the respondents on the average agreed most with the statement that their bosses encourage harmonious relationships between employees, with a mean of 1.74 and a standard deviation of 0.66 . On the average, the mean of the opinion of the respondents that relation-oriented leadership style is more prevalent is 2.16, an indication of an agreement. The standard deviation of 1.10 is also not too large indicating that the instrument is a good measure of the variable.

Furthermore, the Spearman's Correlation test $(r=0.871, \mathrm{p}<0.001)$ revealed a positive relationship between task-oriented leadership style and relation-oriented or person-centered leadership style, and a cumulative look at both Tables 6 and 7 showed that on the average both Task-Oriented and RelationOriented Leadership styles are agreed, by the respondents, to be existing in the General Hospital studied by the respondents, going by their means of 2.11 ( $\mathrm{SD}=1.11)$ and $2.15(\mathrm{SD}=1.10)$ respectively, but with task-oriented leadership style being the more prevalent going by the mean values of Tables 6 and 7, respectively.

\section{See Table 8}

Table 8: The statement stating that their bosses allows flexibility in the way they carry out their duties attracted the highest level of agreement, with a mean of 3.31 and a standard deviation of 1.67. Also, on the average, the mean of Table 8 is 4.29 which is ${ }^{<} 5$ and hence in the region of agreement to the statement as set out in the research methodology for this study, this thus indicates that there is an agreement, though marginal, by the respondents that the present leadership style is compatible with 'New ways of Working'.

\section{Discussion}

The findings of this study indicate that though both task-oriented and relation-oriented leadership styles are prevalent, task-oriented leadership is still dominant. This finding is similar to the outcome of a study conducted to know the leadership style of hospital pharmacy directors, where it was found out that a mixture of highly relationship-oriented and highly task-oriented were prevalent among hospital pharmacy directors (Parrett, Hurd, Northcraft, McGhan \& Bootman, 1985).It has also been opined that a task-oriented leadership will have to be prevalent in an organisation for the "New Ways of Working" to be successfully introduced and implemented in any organization (De Leede \& Kraijenbrink, 2014),though some other authors have asserted that a task-oriented leadership style does not contribute to the implementation of NWW in a financial organization studied in Holland (Stoffers, Kurstjens \& Schrijver, 2015).Bijl, (2001, 2009)however, suggested that it is rather a person-centered leadership style environment that is needed for the successful introduction of "New Ways of 
Working” in any organization, these conflicting recommendations by researchers are not surprising, but what matters is for clinicians to have leadership expertise in all settings to implement change based upon good clinical decision making built around a patient-centered approach to care (Cooper, 2006).

This study also reveals that though the responses of the respondents were on the average, a depiction of neutrality to the variable, that the leadership style prevailing presently in General Hospitals in Nigeria is compatible with the 'New Ways of Working', but the responses were still taken as a marginal agreement to the variable as it was set out in the research methodology for this study. This finding is in tune with the works of some other authors (Bijl, 2007, 2009; De Leede \& Kraijenbrink, 2014), who all established that "New Ways of Working" does not need a mixture of relation-oriented and task-oriented leadership styles that was revealed to be prevailing in this study, but probably either a sole presence of task-oriented or person-centered leadership style, also this their responses may be regarded as precautionary since the 'new Ways of Working is still alien to them and it is after its introduction that they can actually be bold in their assertion of whether the leadership style that is currently in place in their work place would be adequate or not, this can be construed to mean that the attainment of a good leadership in any situation can only be more of a journey than a destination and this could only be recognized in practice (Donnelly, 2003), hence, the best leadership style for the implementation of the 'New Ways of Working' would only evolve as an adaptation process.

\section{Conclusion}

It can be concluded from this study that with the prevalence of both task-oriented and personcentered leadership in General Hospitals in Nigeria, the introduction and implementation of 'New Ways of Working' can still be accommodated, with very little adjustment to the leadership style. However, it is in the interest of all staff of these hospitals to accommodate a new way of working, which apart from giving them flexibility to carry out their work and ultimately achieving the best balance between their work and private lives, also enables patients they serve to derive more satisfaction in the way they are served by these hospital staff.

\section{Tables}

Table 1. Gender of the Respondents

\begin{tabular}{|l|l|l|}
\hline Gender & $\begin{array}{l}\text { Number of } \\
\text { Respondents }\end{array}$ & Percentage \\
\hline Male & 25 & 30.9 \\
\hline Female & 56 & 69.1 \\
\hline Total & $\mathbf{8 1}$ & $\mathbf{1 0 0}$ \\
\hline
\end{tabular}

Table 2. Age range of the Respondents

\begin{tabular}{|l|l|l|}
\hline Age Range & $\begin{array}{l}\text { Number of } \\
\text { Respondents }\end{array}$ & Percentage \\
\hline 25 \& Below & 1 & 1.2 \\
\hline $26-30$ & 11 & 13.6 \\
\hline $31-35$ & 9 & 11.1 \\
\hline $36-40$ & 16 & 19.8 \\
\hline $41-45$ & 19 & 23.5 \\
\hline $46-50$ & 19 & 23.5 \\
\hline $51-55$ & 5 & 6.2 \\
\hline 56 \& Above & 1 & 1.2 \\
\hline
\end{tabular}


Texila International Journal of Public Health

Volume 4, Issue 4, Dec 2016

\begin{tabular}{|l|l|l|}
\hline Total & 81 & 100.0 \\
\hline
\end{tabular}

Table 3. Education level of the Respondents

\begin{tabular}{|l|l|l|}
\hline Education Level & $\begin{array}{l}\text { Number of } \\
\text { Respondents }\end{array}$ & Percentage \\
\hline Secondary School & 2 & 2.5 \\
\hline OND/NCE & 8 & 9.9 \\
\hline $\begin{array}{l}\text { School of Nursing } \\
\text { Certificate }\end{array}$ & 17 & 21.0 \\
\hline Bachelors/HND & 42 & 51.9 \\
\hline Post Graduate Degree & 11 & 13.6 \\
\hline Others & 1 & 1.2 \\
\hline Total & $\mathbf{8 1}$ & $\mathbf{1 0 0}$ \\
\hline
\end{tabular}

Table 4. Socio-Demographic Characteristics of the Respondents

\begin{tabular}{|l|l|l|}
\hline Specialty/Department & $\begin{array}{l}\text { Number of } \\
\text { Respondents }\end{array}$ & Percentage \\
\hline Nursing & 29 & 35.8 \\
\hline Medical & 11 & 13.6 \\
\hline Dental & 3 & 3.7 \\
\hline Pharmacy & 11 & 13.6 \\
\hline Physiotherapy & 2 & 2.5 \\
\hline $\begin{array}{l}\text { Health Information } \\
\text { Management }\end{array}$ & 5 & 6.2 \\
\hline Laboratory & 6 & 7.4 \\
\hline Account & 6 & 7.4 \\
\hline Administration & 5 & 6.2 \\
\hline Medical Social Worker & 3 & 3.7 \\
\hline Total & $\mathbf{8 1}$ & $\mathbf{1 0 0}$ \\
\hline
\end{tabular}

Table 5. Job function of the Respondents

\begin{tabular}{|l|l|l|}
\hline Job Function & & \\
\hline Managerial & 21 & 25.9 \\
\hline Non-Managerial & 60 & 74.1 \\
\hline Total & $\mathbf{8 1}$ & $\mathbf{1 0 0}$ \\
\hline
\end{tabular}


表

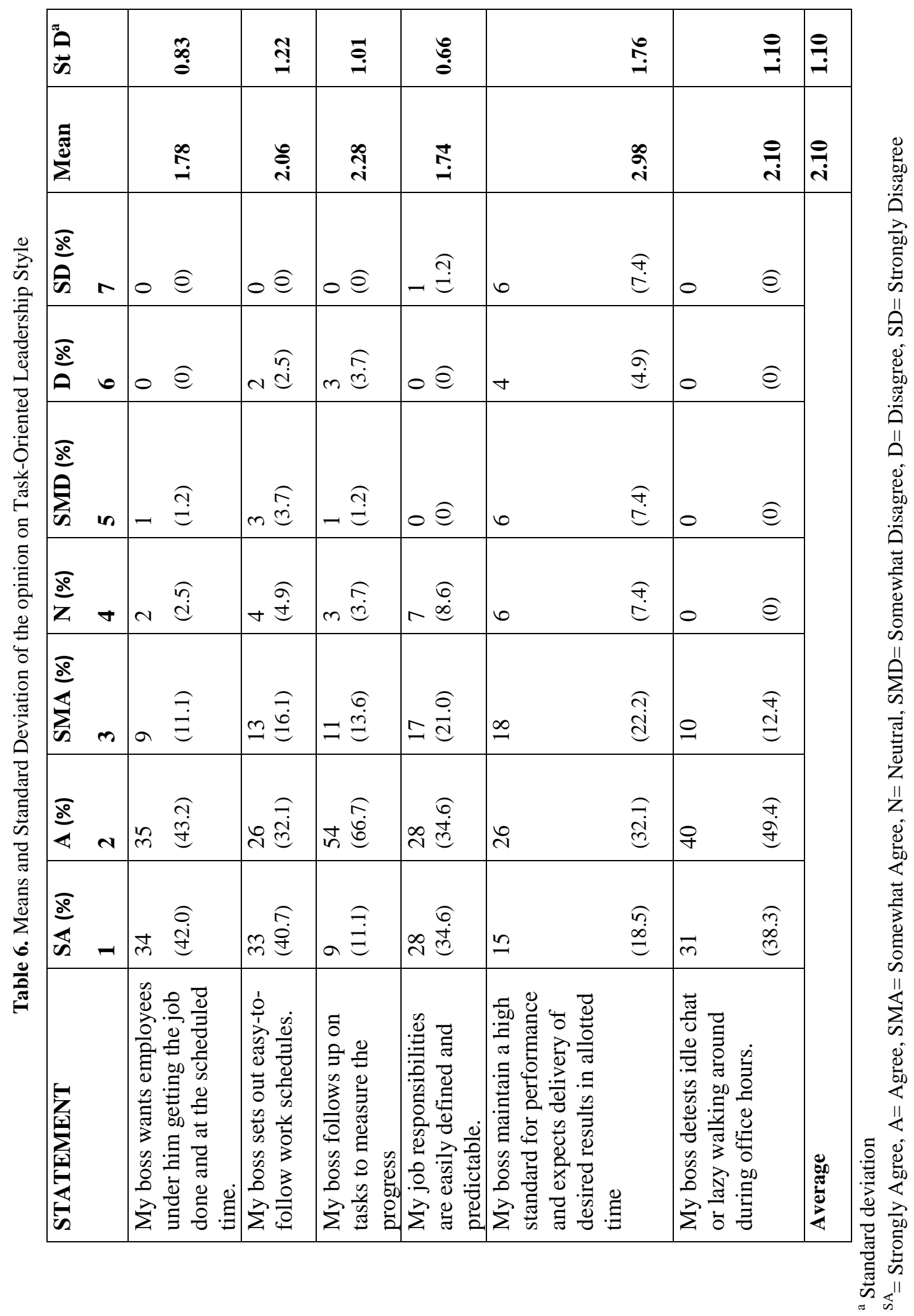




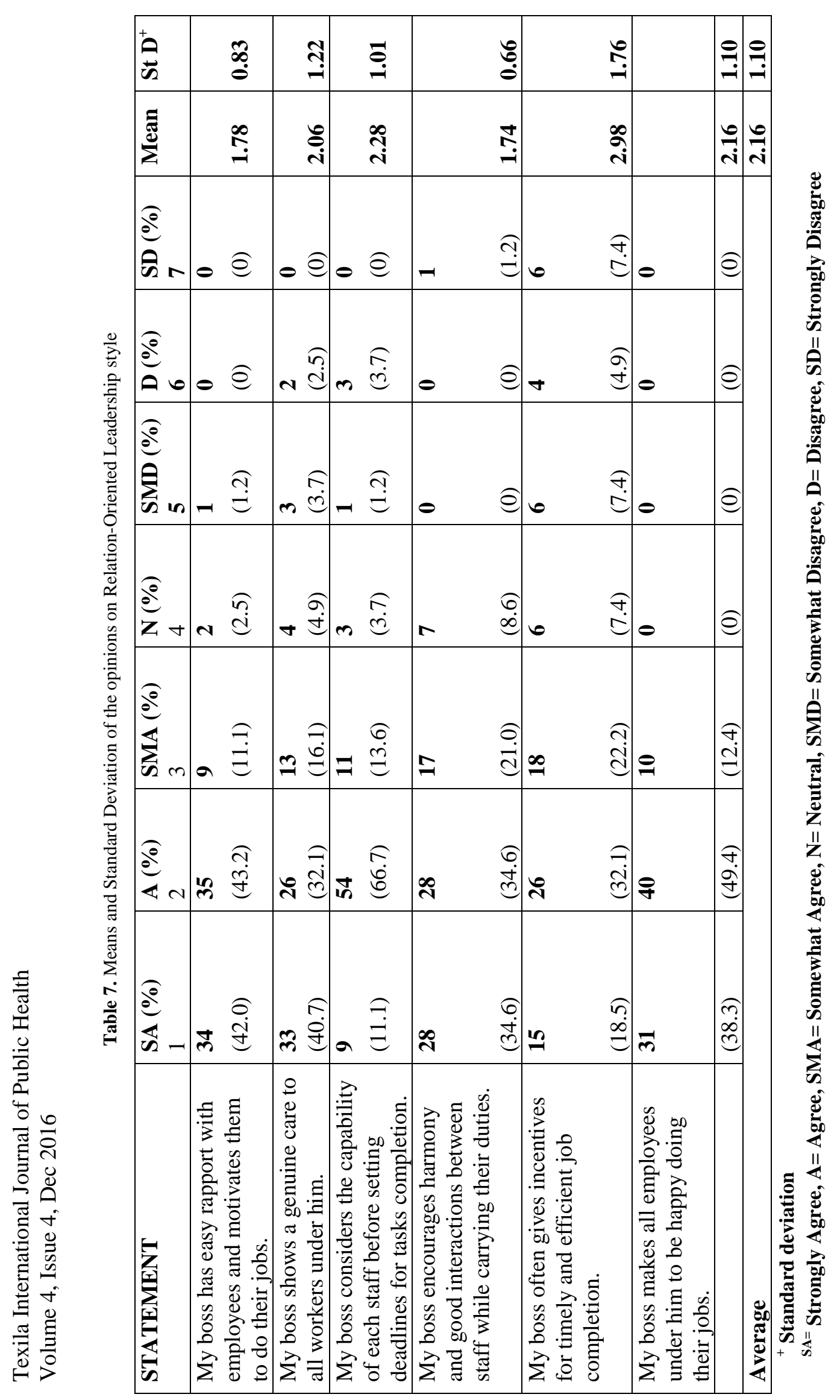


吾

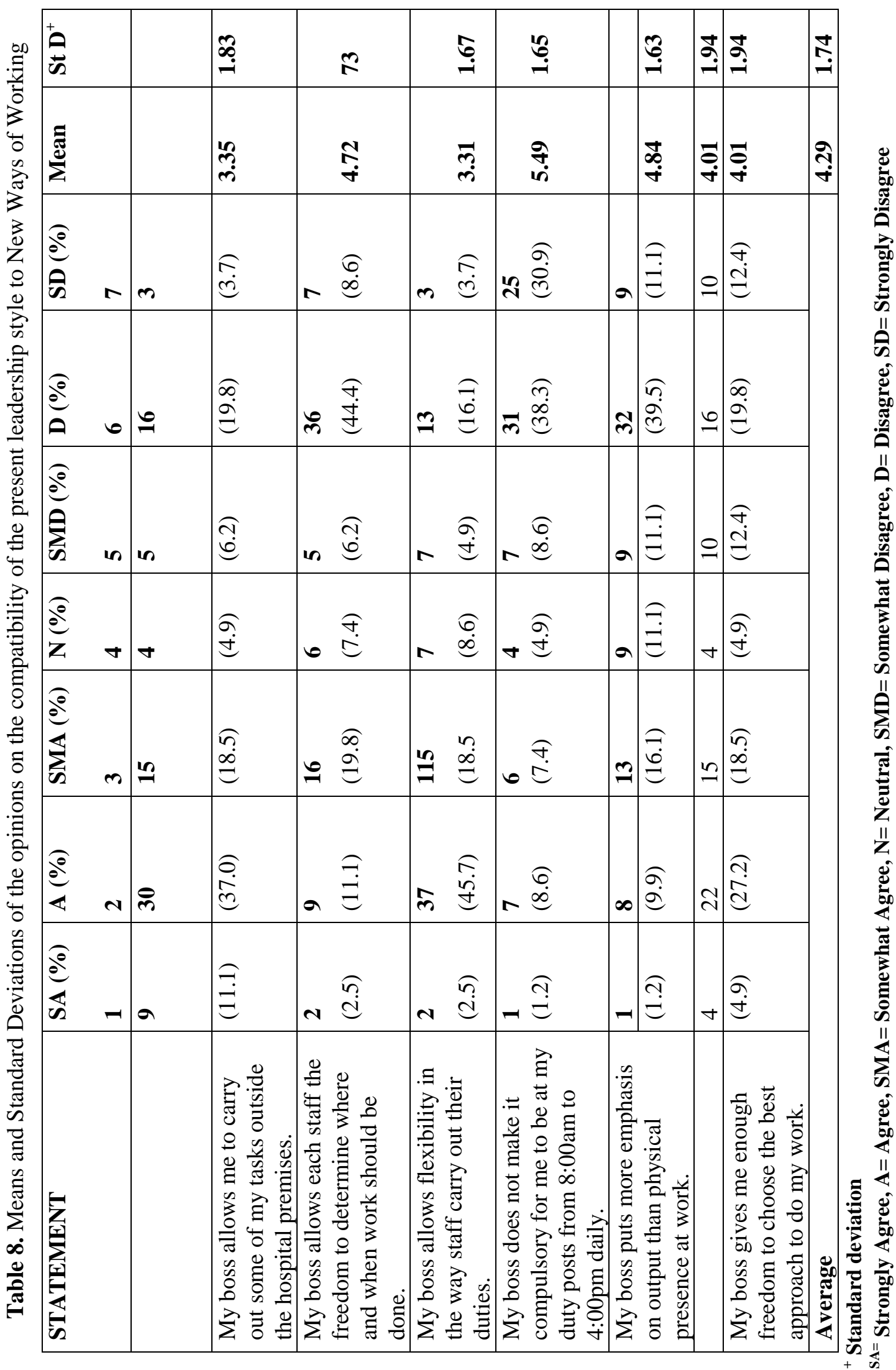


Texila International Journal of Public Health

Volume 4, Issue 4, Dec 2016

\section{References}

[1]. Al-Tawfiq, J.A., Memish, Z.A. (2014). What are our pharmacotherapeutic options for MERS-CoV?Expert Rev. Clin Pharmacol. 2014; 7: 235-238. 10.1586/17512433.2014.890515.

[2]. Baane, R.H., Houtkamp, P., \&Knotter, M. (2010).Het nieuwe werken ontrafeld [New ways of working figured out]. Assen: Koninklijke Van Gorcum; 2010.

[3]. Bijl, D. (2007).Het nieuwe werken: Op weg naar een productieve kenniseconomie [New Ways of working: heading for a productive knowledge economy]. Den Haag: Sdu Publishers bv.2007. Dutch.

[4]. Bijl, D. (2009).Aan de slag met het nieuwe werken [Let's get to the new ways of working]. Zeewolde: Par CC. 2009. Dutch.

[5]. Bryman A. \&Bell, E. (2011). Business Research Methods (3rd edition). New York: Oxford University Press Inc.; 2011.

[6]. Cooper S.J., (2003). An evaluation of the leading an Empowered Organisation Programme. Nursing Standard; 2003: 17(24): 33-9.

[7]. Cronbach, L.J. (1951). Coefficient alpha and the internal structure of tests. Psychometrika. 1951; 16:297334.

[8]. De Leede, J \& Kraijenbrink, J. (2014).The Mediating Role of Trust and Social Cohesion in the Effects of New Ways of Working: A Dutch Case Study. Human Resource Management, Social Innovation and Technology (Advanced Series in Management, Volume 14). England. Emerald Group Publishing Limited, 2014; 14, 3-20.

[9]. Donnelly, G.F. (2003). Why Leadership is important to nursing. In Austin S, Brewer M, Donnelly G, Fitzpatrick MA, Harberson G, Hunt PS, Morris M, editors. Five Steps to Successful Nursing Management. Springhouse, PA: Lippincott, Williams and Wilkins; 2003.

[10]. Dooley, D. (2009). Social research methods. 4th ed. Harlow: Pearson Education Limited; 2009.

[11]. Egmond van, H. (2010).Het nieuwe werken: Van visie naar praktijk [New ways of working: From vision to practice]. Alphen aan den Rijn: Kluwer. 2010. Dutch.

[12]. Fiedle, F.E. (1964). A contingency model of leadership effectiveness. In L. Berkowity (Ed.), Advances in experimental social psychology. New York: Academic Press; 1964: Vol. 1, pp150-190

[13]. Fiedler, F. E. (1966). Personality and situational determinants of leadership effectiveness. In D. Cartwright and A. Zander (Eds.), Group dynamics. 3rd ed. New York: Harper \& Bow; 1966: 302-380.

[14]. Fiedler, F.E. (1967).A theory of leadership effectiveness. McGraw-Hill: Harper and Row Publishers Inc.; 1967.

[15]. Fox, R., Crask, M.\&Kim, J. (1988). Mail survey response rate a meta-analysis of selected techniques for inducing response. Public Opinion Quarterly; 1988: 52(4), 467-491.

[16]. Gautret, P., Benkouiten, S., Salaheddine, I., Belhouchat, K., Drali, T. \&Parola, P. (2013). Hajj pilgrims knowledge about Middle East respiratory syndrome coronavirus, August to September 2013. Euro Surveill. 2013; 18: 20604

[17]. Kluytmans, F. (2005).Leerboek personeels management [Learning book human resource management]. Groningen: Wolters-Noordhoff. 2005. Dutch.

[18]. Lewin, K., Lippit, R, \& White, R.K. (1939). Patterns of aggressive behavior in experimentally created social climates. Journal of Social Psychology, 1939;10, 271-301.

[19]. Memish, Z.A., Al-Tawfiq, J.A., Makhdoom, H.Q. Al-Rabeeah, A.A., Assiri, A., Al-Hakeem, R.F., AlRabaiah, F.A., Alhajjar, S., Flemban, H., Balkhy, H., Barry, M., Alhaassan, S., Alsubaie, S. \& Zumla, A. (2014). Screening for Middle East respiratory syndrome coronavirus infection in hospital patients and their healthcare worker and family contacts: a prospective descriptive study. Clin Microbiol Infect. 2014; 20: 469474. 10.1111/1469-0691.12562.

[20]. Nunnally, J. (1978).Psychometric theory 2nd ed. New York: McGraw-Hill; 1978.

[21]. Parrett, EE.., Hurd, PO.., Northcraft, G., McGhan, W.F.\&Bootman, J.L. (1985). Leadership styles of hospital pharmacy directors. American Journal of Hospital Pharmacy. 1985; 42: 69-73.

[22]. Rowley, R. \& Roevens, J. (1999).Organize with Chaos, Management Books 2000 Ltd. 1999. ISBN 9781852525613. 
[23]. Saunders, M., Lewis, P., Thornhill, A., Booij, M. \& Verckens, J. P. (2011).Methoden en technieken van onderzoek [Methods and techniques of research]. Amsterdam: Pearson Education Benelux; 2011. Dutch.

[24]. Stoffers, J., Kurstjens, J., \& Schrijver I. (2015). Leadership and New Ways of Working: A Case Study in a Financial Service Organisation. International Journal of Business and Economics Research; 2015: Vol. 4, No. 3: 157-162. doi: 10.11648/j.ijber.20150403.18

[25]. Taberno, C., Chambel, M.J., Curral, L. \&Arana, J.M., (2009). The role of task-oriented versus relationship-oriented leadership on normative contract and group performance. Social behavior and personality; 2009: 37(10): 1391-1404. doi: 10.2224/sbp.2009.37.10.1391.

[26]. Volberda, H., Jansen, J., Tempelaar, M. \& Heij, K. (2010). Monitoren van sociale innovatie: Slimmer werken, dynamisch managen en flexible organiseren [Monitoring social innovation: working smarter, dynamic management and organising flexible]. Magazine for HRM, 2010;1, 85-110. Dutch.

[27]. WHO (2013). MERS-CoV Research Group. State of knowledge and data gaps of Middle East Respiratory Syndrome coronavirus (MERS-CoV) in humans. PLoS Curr. 2013; 5: 